\title{
PERAN MANAJEMEN SYARIAH TERHADAP PENINGKATAN KEPUASAN PELANGGAN PADA RUMAH SAKIT ISLAM DI KOTA SURAKARTA
}

\author{
SUMADI \\ STIE - AAS Surakarta \\ Email: ahmadsumadi1924@gmail.com
}

\begin{abstract}
Abstrak
This study aims to find customer satisfaction model at Islamic Hospital in Surakarta. The sample in this study is the respondents who have come and treated in the Islamic Hospital in the city of Surakarta. With various limitations, the target object is the community around the solo who ever come to the hotel sharia. The spread of questionnaires is not necessarily done in Islamic Hospital by looking and giving directly to visitors who come to the place of Islamic Hospital. The criteria used are the people around the solo who already know about the Islamic Hospital and have visited the treatment and never stay in the Islamic Hospital which amounted to 57 respondents. The sampling technique in this research is by accidental sampling. Data analysis method used is validity test, reability test, normality test and multiple linear regression analysis test with t test, $F$ test, and coefficient of determination (R2).
\end{abstract}

Keywords: satisfaction, consumer, accidental sampling, hospital, Islam

\section{Pendahuluan}

Kepuasan konsumen dalam industri jasa begitu penting selama beberapa tahun. Pelayanan dengan kualitas yang unggul dan peningkatan kepuasan konsumen telah dikenal luas sebagai beberapa faktor utama yang penting untuk kesuksesan perusahaan perhotelan,rumah sakit, katering dan industri pariwisata (Barsky \& Labagh, 1992a; Choi \& Chu, 2001; Legoherel, 1998). Ketika konsumen puas maka akan mudah membangun loyalitas, pembelian berulang dan pemasaran dari mulut ke mulut (Fornell, 1992). Kepuasan konsumen pada perhotelan terdiri dari banyak faktor, diantaranya adalah keramahan pelayanan kepada konsumen, fasilitas dan harga (Skogland, I. \& Siguaw, 2004).

Menurut Thorik \& Utus (2006), pentingnya memberikan pelayanan yang berkualitas disebabkan pelayanan (service) tidak hanya sebatas mengantarkan atau melayani. Service berarti mengerti, memahami, dan merasakan sehingga penyampaiannya pun akan mengenai heart share konsumen dan pada akhirnya memperkokoh posisi dalam mind share konsumen. Dengan adanya heart share dan mind share yang tertanam, loyalitas seorang konsumen pada produk atau usaha perusahaan tidak akan diragukan. Konsumen akan memberikan umpan balik positif berupah loyalitas, loyalitas terbentuk apabila fasilitas yang baik dan memadahi serta kepuasan yang diterima melaui tingkat pelayanan yang diterima (Arifin, 2011).

Pelayanan merupakan faktor yang sangat penting khususnya bagi perusahaan yang bergerak dibidang jasa. Pelayanan ditentukan oleh manajemennya, manajemen yang baik serta sesuai dengan ketentuan akan menjadikan pelayanan menjadi baik, terlebih sesuai dengan syariah agama Islam, sehingga manajemennya menjadi manajemen syariah. Dimana menurut Tho'in (2016) Syariah Islam adalah sebuah aturan hukum yang ditetapkan oleh Allah SWT untuk kemaslahatan seluruh ummat manusia. Adapun inti produk yang dimaksud biasanya merupakan jasa tertentu. Oleh karena itu pentingnya mengetahui secara teoritis tentang batasan, pengertian, dan faktor-faktor yang mempengaruhi dari pada pelayanan itu sendiri. 
Pelayanan pelanggan ini sangat penting artinya bagi kehidupan suatu perusahaan, karena tanpa pelanggan, maka tidak akan terjadi transaksi diantara keduanya. Untuk itu kegiatan pelayanan perusahaan haruslah berorientasi pada kepuasan pelanggan. Pengertian kualitas pelayanan menurut Supranto (2001) adalah sebuah kata yang bagi penyedia jasa merupakan sesuatu yang harus dikerjakan dengan baik. Sedangkan definisi pelayanan menurut Gronroos dalam Ratminto \& Winarsih (2005) adalah suatu aktivitas atau seluruh rangkaian aktivitas yang bersifat tidak kasat mata yang terjadi sebagai akibat adanya interaksi antara konsumen dengan karyawan atau hal-hal lain yang disediakan oleh perusahaan pemberi pelayanan yang dimaksud untuk memecahkan permasalahan konsumen pelanggan.

Berdasarkan latar belakang tersebut, penelitian ini fokus model kepuasan konsumen rumah sakit Islam. Model adalah penyederhanaan pola hubungan searah suatu variabel yang satu dengan dengan variabel yang lain yang menggambarkan fenomena dunia nyata. Tujuan pembuatan sebuah model adalah untuk menganalisis dan memprediksi. Didalam pembuatan model harus realisitis didasarkan pada bidang yang dipelajari. Menurut Kendall dan Stuart dalam Gujarati (2006), bahwa suatu hubungan statistik, bagaimanapun kuat dan sugestif, tidak pernah dapat menetapkan hubungan sebabakibat, gagasan sebab-akibat harus datang dari luar statistik. Salah satu gagasan sebab akibat dari luar statistik adalah hubungan antar variabel ekonomi. Dalam hal ini, akan dikaji variabel-variabel apa saja yang mempengaruhi kepuasan konsumen RS Islam di Surakarta.

\section{Pembahasan}

\section{Kepuasan Konsumen}

Kepuasan konsumen telah menjadi topik yang populer dalam praktek pemasaran.
Penelitian yang dilakukan oleh Cardozo (1965) mengenai harapan dan kepuasan konsumen. Meskipun banyak upaya untuk mengukur dan menjelaskan kepuasan konsumen, masih belum ada kesepakatan dalam mendefinisikannya (Giese \& J.A, 2000). Kepuasan konsumen biasanya didefinisikan sebagai penilaian evaluatif konsumsi tentang produk atau layanan tertentu (Gundersen, Heide, \& Olson, 1996). Ini adalah hasil dari sebuah proses evaluatif yang kontras harapan sebelum pembelian dengan persepsi kinerja selama dan setelah pengalaman mengkonsumsi (Oliver, 1980).

Konseptualisasi yang paling banyak diterima dari konsep kepuasan pelanggan adalah teori diskonfirmasi harapan (Barsky \& Labagh, 1992a; Finn, Elliot-White, \& Walton, 2000; Oh \& Parks, 1997). Teori ini dikembangkan oleh Oliver (1980), yang mengusulkan bahwa tingkat kepuasan adalah hasil dari perbedaan antara kinerja yang diharapkan dan dirasakan. Kepuasan (disconfirmation positif) terjadi ketika produk atau layanan yang lebih baik dari yang diharapkan. Di sisi lain, kinerja buruk dari hasil yang diharapkan dengan ketidakpuasan (negatif disconfirmation).

Studi menunjukkan bahwa kepuasan pelanggan berdampak langsung dan tidak langsung pada hasil bisnis. Anderson, Fornell, \& Lehmann (1994); Luo \& Homburg (2007); Yeung, Ging, \& Ennew (2000) menyimpulkan bahwa kepuasan pelanggan secara positif mempengaruhi profitabilitas bisnis. Mayoritas studi telah meneliti hubungan dengan pola perilaku pelanggan (Chi \& Qu, 2008; Dimitriades, 2006; Faullant, Matzler, \& Füller, 2008; Kandampully \& Suhartanto, 2000; Olorunniwo, Hsu, \& Udo, 2006; Söderlund, 1998). Menurut temuan ini, kepuasan pelanggan meningkatkan loyalitas pelanggan, pengaruh niat pembelian kembali dan mengarah ke pemasaran dari mulut ke mulut berdampak positif. 
Mengingat peran penting dari kepuasan pelanggan, tidak mengherankan bahwa berbagai penelitian telah dikhususkan untuk menyelidiki faktor penentu kepuasan (Barsky \& Labagh, 1992; Churchill \& Surprenant, 1982; Oliver, 1980; Zeithaml \& Bitner, 2003). Kepuasan dapat ditentukan dengan subjektif (seperti: Kebutuhan pelanggan, emosi) dan faktor obyektif (seperti, Produk dan layanan fitur). Ada banyak studi yang meneliti atribut kepuasan pelanggan dari jasa perhotelan dan pariwisata. Atkinson (1988) menemukan bahwa kebersihan, keamanan, nilai uang dan kesopanan staf menentukan kepuasan pelanggan. Knutson (1988) mengungkapkan bahwa kebersihan kamar dan kenyamanan, kenyamanan lokasi, layanan yang cepat, keselamatan dan keamanan, dan keramahan karyawan yang penting. Barsky \& Labagh (1992) menyatakan bahwa sikap karyawan, lokasi dan kamar cenderung mempengaruhi kepuasan wisatawan. Sebuah studi yang dilakukan oleh Akan (1995) menunjukkan bahwa faktor penentu utama kepuasan tamu hotel adalah perilaku karyawan, kebersihan dan ketepatan waktu. Choi \& Chu (2001) menyimpulkan bahwa kualitas staf, kualitas kamar dan nilai organisasi merupakan ketiga faktor yang menentukan kepuasan tamu hotel. Menurud Irawan (2004), faktor-faktor yang mendorong kepuasan pelanggan adalah sebagai berikut:

a. Kualitas produk, pelanggan puas kalau setelah membeli dan menggunakan produk tersebut ternyata kualitas produk tersebut baik.

b. Harga, untuk pelanggan yang sensitif, biasanya harga murah adalah sumber kepuasan yang penting karena pelanggan akan mendapatkan value of money yang tinggi.

c. Service quality, kepuasan terhadap kualitas pelayanan biasanya sulit ditiru. Kualitas pelayanan merupakan driver yang mempunyai banyak dimensi.

d. Emotional factor, pelanggan akan merasa puas (bangga) karena adanya emosional value JURNAL ILMIAH EKONOMI ISLAM, ISSN: 2477-6157 ; E-ISSN 2579-6534 yang diberikan oleh brand dari produk tersebut.

e. Biaya dan kemudahan, pelanggan akan semakin puas apabila relatif mudah, nyaman dan efesien dalam mendapatkan produk atau pelayanan.

Menurud Tjiptono indikator kepuasan yang diteliti sebagai evaluasi atas kepuasan berkaitan dengan (Tjiptono, 2004):

a. Penyediaan layanan yang baik

b. Karyawan cepat dalam menyelesaikan pekerjaan

c. Karyawan tanggap terhadap keluhan konsumen

d. Karyawan mampu mengetahui keinginan dan mendiagnosis hal yang harus dilakukan dengan cepat.

e. Karyawan memberikan perhatian individu dengan baik kepada keluhan konsumen.

Metode yang digunakan setiap perusahaan untuk mengukur kepuasan pelanggan (Kotler, 2005), yaitu:

\section{a. Lost costomer analysis}

Perusahaan seharusnya menghubungi para pelanggan yang telah berhenti membeli atau yang telah beralih pemasok agar dapat memahami mengapa hal tersebut terjadi dan supaya dapat mengambil kebijakan perbaikan/penyempurnaan selanjutnya.

b. Ghost shopping (mystery shopping)

Salah satu metode untuk memperoleh gambaran mengenai kepuasan pelanggan adalah dengan memperkerjakan beberapa orang ghost shoppers untuk berperan sebagai pelanggan potensial jasa perusahaan dan pesaing. Mereka diminta melaporkan berbagai pertemuan penting berdasarkan pengalamannya mengenai kekuatan dan kelemahan jasa perusahaan dibandingkan para pesaing. Lalu ghost shopper juga dapat mengobservasi cara peusahaan dan pesaing melayani permintaan spesifik pelanggan, menjawab pertanyaan pelanggan, dan 
menangani setiap masalah atau keluhan pelanggan.

c. Sistem keluhan dan saran

Setiap perusahaan jasa yang berorientasi pada pelanggan wajib memberikan kesempatan seluas-luasnya bagi para pelanggannya untuk menyampaikan saran, kritik, pendapat dan keluhan mereka. Media yang digunakan bisa berupa kotak saran di letakan ditempat-tempat yang strategis (yang mudah diakses atau sering dilalui pelanggan), saluran telepon khusus bebas pulsa, website, dan lain-lain. Informasi-informasi yang diperoleh melalui metode ini dapat memberikan ide-ide baru dan masukan berharga bagi perusahaan, sehingga memungkinkanya untuk bereaksi dengan tanggap dan cepat untuk mengatasi msalahmasalah yang timbul.

d. Survei kepuasan pelanggan

Umumnya sebagian penelitian mengenai kepuasan pelanggan menggunakan metode survei, via pos, telepon, e-mail, ataupn wawancara langsung.

Setiap perusahaan yang memperhatikan kepuasan pelanggann akan memperoleh beberapa manfaat pokok sebagai berikut (Tjiptono, 2004) :

a. Reputasi perusahan semakin positif di mata masyarakat pada umumnya dan pelanggan pada khususnya.

b. Dapat mendorong terciptanya loyalitas pelanggan.

c. Memungkinkan terciptanya rekomendasi dari mulut ke mulut (word of mouth) yang menguntungkan bagi perusahaan sehingga semakin banyak orang yang akan membeli dan menggunakan produk/jasa perusahaan.

d. Meningkatkan volume penjualan dan keuntungan.

e. Hubungan antara perusahaan dan para pelanggan menjadi harmonis.

Menurud Tjiptono (2004) metode pengukuran kepuasan konsumen diantaranya dapat dilakukan dengan metode directly reported JURNAL ILMIAH EKONOMI ISLAM, ISSN: 2477-6157 ; E-ISSN 2579-6534 satisfaction, yaitu pengukuran dilakukan secara langsung melalui pertanyaan, misalnya memberikan alternatif jawaban pada pertanyaanpertanyaan yang diajukan kepada konsumen mulai dari Sangat Tidak Puas, Tidak Puas, Netral, Puas, Sangat Puas.

\section{Kualitas Pelayanan}

1. Pengertian Kualitas Pelayanan

Kualitas pelayanan dipandang sebagai salah satu komponen yang perlu diwujudkan oleh perusahaan, karena memiliki pengaruh untuk mendatangkan konsumen baru. Kualitas pelayanan didefinisikan sebagai tingkat keunggulan yang diharapkan dan pengendalian atas tingkat keunggulan tersebut untuk untuk memenuhi keinginan pelanggan (Fandy, 2008). Pelayanan menurut Kotler (2005) adalah kegiatan atau manfaat yang dpat diberikan oleh suatu pihak lain yang pada dasarnya tidak berwujud dan tidak pula berakibat pemilihan suatu. Sedangkan menurut Tjiptono (2004) merupakan setiap tindakan atau perbuatan yang dapat ditawarkan oleh suatu pihak kepada pihak lain yang pada dasarnya bersifat intangible (tidak berwujud fisik) dan tidak menghasilkan kepemilikan sesuatu.

Mengacu pada pengertian kualitas pelayanan tersebut maka konsep kualitas pelayanan adalah suatu daya tanggap dan realitas jasa yang diberikan perusahaan. Kualitas pelayanan harus dimulai dari kebutuhan pelanggan dan berakir pada persepsi pelanggan (Kotler, 2005). Menurut Tho'in (2011) kualitas jasa menjadi suatu item penting yang harus diperhatikan. Agar pelayanan yang diberikan dapat berkualitas baik dan dapat memberikan kepuasan pada konsumennya maka sebaiknya perusahaan perlu memperhatikan berbagai dimensi yang bisa menciptakan dan meningkatkan kualitas pelayanan. 
Menurut Ratnasari \& Mastuti (2011), kualitas pelayanan adalah seberapa jauh perbedan antara kenyatan dan harapan konsumen atas pelayanan yang diterima/diperoleh. Sebelum konsumen membeli suatu jasa, konsumen memiliki harapan tentang kualitas pelayanan yang didasarkan pada kebutuhan-kebutuhan pribadi, pengalaman-pengalaman sebelumnya, rekomendasi dari mulut ke mulut, dan iklan penyedia jasa. Setelah membeli dan menggunakan jasa tersebut, konsumen membandingkan kualitas yang diharapkan dengan apa yang benar-benar diterima (Lovelock \& Wright, 2007). Menurut Arifin (2011) merupakan suatu kondisi yang berhubungan dengan produk atau jasa manusia, proses dan lingkungan yang memenuhi harapan.

Dari pengertian di atas dapat dikatakan bahwa pelayanan yang diberikan perusahaan adalah suatu usaha yang dilakukan dalam upaya untuk dapat memberikan kepuasan pada konsumennya. Dalam hal ini pelayanan mencakup tentang kelengkapan yang digunakan, keramahtamahan, kegiatan, ketepatan serta pertanggungjawaban bila terjadi kerusakan pada produk yang sudah dibelinya. Masalah pelayanan ini sangat penting artinya bagi konsumen, oleh karena itu perlu mendapatkan perhatian yang sungguh-sungguh dari perusahaan. Pelayanan yang diberikan sehubungan dengan jual beli barang atau jasa merupakan kunci kesuksesan suatu usaha di dalam menjalankan suatu usaha.

Menurut Lupiyoadi, Rambat (2006) berpendapat kehandalan (reliability) yaitu kemampuan perusahaan untuk memberikan pelayanan seusai dengan apa yang dijanjikan secara akurat dan terpercaya. Kinerja harus sesuai dengan harapan pelanggan yang berarti ketepatan waktu, pelayanan yang sama untuk JURNAL ILMIAH EKONOMI ISLAM, ISSN: 2477-6157 ; E-ISSN 2579-6534 semua pelanggan tanpa kesalahan, sikap yang simpatik, dan dengan akurasi yang tinggi. Pemenuhan janji dalam pelayanan akan mencerminkan kredibilitas perusahaan. Atribut-atribut dalam dimensi ini antara lain adalah:

a. Memberikan pelayanan sesuai janji.

b. Pertanggung jawaban tentang penanganan konsumen akan masalah pelayanan.

c. Memberikan pelayanan yang baik saat kesan pertama kepada konsumen, dan tidak membedakan satu dengan yang lainnya.

d. Memberikan pelayanan tepat waktu.

e. Memberikan informasi kepada konsumen tentang kapan pelayanan yang dijanjikan akan direalisasikan.

2. Konsep kualitas jasa

Lovelock \& Wright (2007) mengidentifikasi delapan kategori unsur layanan pelengkap pada setiap penawaran produk yang disebutnya "The Flower of Services".

a. informasi, misalnya jalan/arah menuju tempat produsen, jadwal atau skedul penyampaian produk, harga, intruksi mengenai cara menggunakan produk inti atau layanan pelengkap, pringatan (warnings), persyaratan penjualan/reservasi, rekapitulasi rekening, tanda terim, dan tiket.

b. Konsultasi, seperti pemberian saran, auditing, konseling pribadi, dan konsultasi manajemen/teknis.

c. Order taking, meliputi aplikasi (keanggotaan di klub atau program tertentu), jasa langganan, jasa berbasis kualifikasi (misalnya perguruan tinggi), order entry, dan reservasi (tempat duduk, meja, ruang, professional appointments dan admisi untuk fasilitas yang terbatas seperti pameran) 
d. Hospitality, di antaranya sambutan, food and beverages, toilet dan kamar kecil, perlengkapan kamar mandi, fasilitas menunggu (majalah, hiburan, Koran, ruang tunggu), transportasi, dan jasa keamanan.

e. Caretaking, terdiri dari perhatian dan perlindungan atas barang milik pelanggan yang mereka bawa (parker kendaraan roda dua dan roda empat, penanganan bagasi, titipan tas, dan lain-lain), serta perhatian dan perlindungan atas barang yang dibeli pelanggan (pengemasan, transportasi, pemeliharaan, preventif reparasi dan inovasi).

f. Exsceptions, meliputi permintaan khusus sebelum penyampaian produk, menangani komplain/pujian/saran, penyelesaian masalah (jaminan dan garansi atas kegagalan pemakaian produk)

g. Billing, meliputi laporan rekening periodik, faktur untuk transaksi individual, laporan verbal mengenai jumlah rekening, mesin yang memperlihatkan jumlah rekening dan self-billing.

h. Pembayaran, dalam bentuk pembayaran swalayan oleh pelanggan, pelanggan berintraksi dengan personil perusahaan yang menerima pembayaran.

Menurut Lupiyoadi, Rambat (2006) bahwa kualitas pelayanan memiliki indikator terdiri dari:

a. Wujud fisik (tangible) terdiri dari sub indikator seperti gedung dan ruangan, tersedia tempat parkir, kebersihan, kerapian dan kenyamanan ruangan, kelengkapan peralatan, sarana komunikasi serta penampilan karyawan

b. Kehandalan (reliability) terdiri dari sub indikator memberikan pelayanan sesuai janji, pertanggungjawaban tentang penanganan konsumen akan masalah pelayanan, memberikan pelayanan yang baik saat kesan pertama kepada konsumen, dan tidak membedakannya satu dengan yang lainnya, memberikan pelayanan tepat waktu, memberikan informasi kepada konsumen tentang kapan pelayanan yang dijanjikan akan direalisasikan.

c. Daya tanggap (responsiveness) terdiri dari sub indikator pelayanan responsif dan cepat, pelayanan yang tepat pada konsumen, dan penyampaian infomrasi yang jelas.

d. Keyakinan (assurance) terdiri dari sub indikator pengetahuan terhadap produk secara tepat, kesopan santunan karyawan dalam memberi pelayanan, keterampilan dalam memberikan informasi, kemampuan dalam memberikan keamanan dan kemampuan dalam menanamkan kepercayaan dan keyakinan pelanggan terhadap perusahaan.

e. Empati (empathy), terdiri dari sub indikator kemudahan melakukan hubungan, komunikasi yang baik, perhatian pribadi dan memahami kebutuhan para pelanggan.

\section{Harga}

Menurut Guntur (2010) harga merupakan satuan moneter atau ukuran lainnya (termasuk barang atau jasa lainnya) yang ditukarkan agar memperoleh hak kepemilikan atau pengguna suatu barang atau jasa. Dari sudut pandang konsumen, harga sering kali digunakan sebagai indikator nilai bilamana harga tersebut dihubungkan dengan manfaat yang dirasakan atas suatu barang atau jasa. Dengan demikian dapat disimpulkan bahwa pada tingkat harga tertentu, bila manfaat yang dirasakan konsumen meningkat maka nilainya akan meningkat pula (Tjiptono, 2004). Zeithaml \& Bitner (2003) harga adalah apa yang kita dapat dari suatu yang telah dikorbankan untuk memperoleh produk atau jasa. Kotler \& Armstrong (2006) berpendapat bahwa harga adalah sejumlah uang yang dibebankan suatu produk atau jasa tersebut. Produk dengan mutu jelek, harga yang mahal, 
penyerahan produk yang lambat dapat membuat pelanggan tidak puas. Hal ini menunjukan bahwa harga merupakan salah satu penyebab ketidakpuasan para pelanggan. Fandy (2008) mendefinisikan harga dari dua sudut pandang, yakni dari sudut pandang pemasaran, harga merupakan satuan moneter atau ukuran lainnya (termasuk barang dan jasa lain) yang ditukar agar memperoleh hak kepemilikan atau penggunan suatu barang atau jasa.

Harga merupakan suatu variabel penting dalam pemasaran, dimana harga dapat mempengaruhi pelanggan dalam mengambil keputusan untuk membeli suatu produk, karena berbagai alasan (Ferdinand, 2000). Alasan ekonomis akan menunjukan bahwa harga yang rendah atau harga yang selalu berkompetisi merupakan salah satu pemicu penting untuk meningkatkan kinerja pemasaran, tetapi alasan psikologis dapat menunjukan bahwa harga justru merupakan indikator yang dirancang sebagai salah satu instrument penjualan sekaligus sebagai instrument kompetisi yang menentukan.

Beberapa definisi harga sebelumnya, dapat disimpulkan bahwa harga adalah suatu uang yang ditentukan oleh perusahaan sebagai imbalan barang atau jasa yang diperdagangkan dan suatu yang lain yang diadakan suatu perusahaan guna memuaskan keinginan pelanggan. Kesuksesan pemasaran suatu barang atau jasa, setiap perusahaan harus menetapkan harganya secara tepat. Sekurang-kurangnya ada tiga pihak yang harus menjadi dasar pertimbangan bagi perusahaan dalam menetapkan harga yaitu konsumen, perusahaan yang bersangkutan, dan pesaing. Perusahaan memperhatikan apa yang diinginkan konsumen, yaitu membayar harga yang sepadan dengan nilai yang diperoleh (value of money).

Alasan ekonomis akan menunjukan bahwa harga yang rendah atau harga yang selalu berkompetisi merupakan salah satu pemicu penting untuk meningkatkan kinerja pemasaran, JURNAL ILMIAH EKONOMI ISLAM, ISSN: 2477-6157 ; E-ISSN 2579-6534 tetapi alasan psikologis dapat menunjukan bahwa harga justru merupakan indikator kualitas dan karena itu dirancang sebagai salah satu instrument penjualan sekaligus sebagai instrument kompetisi yang menentukan. Gitosudarmo (2008) berpendapat bahwa Harga adalah sejumlah uang yang dibutuhkan untuk mendapat sejumlah barang beserta jasa-jasa tertentu atau kombinasi dari keduanya. Menurut Lupiyoadi (2013) harga adalah sebagai manfaat yang dimiliki oleh suatu produk jasa yang dibandingkan dengan berbagai biaya (pengorbanan) yang ditimbulkan dalam mengonsumsi jasa tersebut. Biaya-biaya tersebut dapat berupa waktu yang harus dikorbankan untuk mendapat jasa, upaya fisik (energi yang dikeluarkan untuk mendapat jasa), beban mental (stres), dan pengorbanan yang terkait dengan pancaindra (suara bising, panas, dan sebagainya).

Harga sebagai atribut dapat diartikan bahwa harga merupakan konsep keanekaragaman yang memilikin arti berbeda bagi tiap konsumen tergantungg karakteristik konsumen situasi dan produk (Fuady, 2005). Dengan kata lain pada tingkat harga tentu yang telah dikeluarkan, konsumen dapat merasa manfaat dari produk yang telah dibelinya. Pengartian harga dalam penelitian ini adalah tingkat kemampuan seseorang untuk menilai suatu barang dengan nilai atau satuan alat ukur rupiah sehingga dapat memiliki barang atau jasa yang ditawarkan, sehingga setiap orang jika membeli suatu produk pasti mempunyai pendapat yang berbeda tentang harga, hal ini dilihat dari sudut pandang seseorang satu berbeda dengan yang lain karena mempunyai kemampuan beli yang berbeda. Lamarto (1996) menyatakan bahwa istilah harga adalah jumlah nilai (kemungkinan ditambah beberapa barang) yang dibutuhkan untuk memoeroleh beberapa kombinasi sebuah produk dan pelayanan yang menyertainya.

Chandra (2002), harga merupakan satu elemen bauran pemasaran yang membutuhkan 
pertimbangan cermat, ini karena ada sejumlah strategi harga dalam hal:

a. Harga merupakan aspek yang tampak jelas (visible) bagi para pembeli. Bagi konsumen yang tidak terlalu paham hal-hal teknis pada pembelian produk otomatif dan elektronik, kerapkali harga menjadi satu-satunya faktor yang dapat mereka mengerti. Tidak jarang pula harga dijadikan indikator kualitas.

b. Harga adalah determinan utama permintaan. Berdasarkan hukum permintaan (the law of demand), besar kecilnya harga mempengaruhi kualitas produk yang di beli konsumen.

c. Harga berkaitan langsung dengan pendapatan dan laba. Harga adalah satunya unsur bauran pemasaran yang mendatangkan pemasukan bagi perusahaan yang pada gilirannya berpengaruh pada besar kecilnya laba dan pangsa pasar yang diperoleh. Unsur bauran pemasaran lainnya seperto produk, distribusi dan promosi, malah mengeluarkan dana dalam jumlah yang tidak sedikit.

Strategi-strategi ini dirangkum dalam tiga kelompok utama yang saling berkaitan, yakni Satisfication-based pricing, relationship pricing dan efficiency pricing.

a. Satisfaction-based pricing

Karakteristik intangibilitas jasa menghadirkan tantangan bagi perusahaan dan pelanggan dalam hal penciptaan nilai jasa secara jelas. Tujuan utama satisfaction-based pricing adalah untuk mengurangi ketidakpastian yang didasarkan pelanggan.

b. Relationship pricing

Pada prinsipnya Relationship marketing merupakan supaya menarik, mempertahankan, dan meningkatkan relasi dengan pelanggan.

c. Ficiencyc pricing

Aspek utama dalam strategi ini adalah pemahaman, pengelolahan dan penekanan biaya. Sebagian atau seluruh penghematan biaya akan diteruskan kepada para pelanggan dalam bentuk harga lebih murah.

\section{Fasilitas}

Fasilitas merupakan segala sesuatu yang memudahkan konsumen dalam usaha yang bergerak dibidang jasa, maka segala fasilitas yang ada yaitu kondisi fasilitas, kelengkapan, desain interior dan eksterior serta kebersihan fasilitas harus diperhatikanterutama yang berkaitan erat dengan apa yang dirasakan atau didapatkan konsumen secara langsung. Kotler \& Keller (2006) mendefinisikan fasilitas yaitu segala sesuatu yang bersifat peralatan fisik dan disediakan oleh pihak penjual jasa untuk mendukung kenyamanan konsumen. Menurut Kotler (2001) menyatakan bahwa salah satu upaya yang dilakukan manajemen perusahaan terutama yang berhubungan langsung dengan kepuasan konsumen yaitu dengan memberi fasilitas sebaik-baiknya demi menarik dam mempertahankan pelanggan. Fasilitas merupakan sarana maupun prasarana yang penting dalam usaha meningkatkan kepuasan seperti memberi kemudahan, memenuhi kebutuhan dan kenyamanan bagi pengguna jasa. Apabila fasilitas yang digunakan sesuai dengan kebutuhan, maka konsumen akan merasa puas.

Fandy (2006) desain dan tata letak desain jasa erat kaitannya dengan pembentukan presepsi pelanggan. Sejumlah tipe jasa, presepsi yang terbentuk dari interaksi antara pelanggan dengan fasilitas berpengaruh terhadap kualitas jasa tersebut dimata pelanggan. Faktor-faktor yang berpengaruh segnifikan terhadap desain fasilitas jasa adalah sebagai berikut:

a. Sifat dan Tujuan Organisasi.

Sifat suatu jasa seringkali menentukan berbagai persyaratan desainnya. Sebagai contoh, desain rumah sakit perlu mempertimbangkan ventilasi yang memadai, ruang peralatan medis yang representative, ruang tunggu pasien yang nyaman (dilengkapi $\mathrm{TV}$, tersedia cukup tempat untuk 'selonjor' atau untuk berbaring), kamar pasien yang bersih dan nyaman, ruang dokter dan kamar 
peraktik yang bisa menjamin privacy (misalnya kedap suara dan tidak tembus pandang.

b. Ketersediaan tanah dan Kebutuhan akan ruang/tempat.

Setiap perusahaan jasa membutuhkan lokasi fisikuntuk mendirikan fasilitas jasanya. Dalam menentukan lokasi fisik diperlukan beberapa faktor yaitu kemampuan finansial, peraturan pemerintah berkaitan dengan kepemilikan tanah dan pembebasan tanah, dan lain-lain.

c. Fleksibilitas

Fleksibilitas desain sangat dibutuhkan apabila volume permintaan sering berfluktuasi dan jika spesifikasi jasa cepat berkembang, sehingga risiko keusangan relatife besar. Kedua kondisi ini menyebabkan fasilitas jasa harus dapat disesuaikan secara mudah dengan memperhitungkan kemungkinan perkembangan di masa datang.

d. Faktor Estesis

Fasilitas jasa yang tertata secara rapi, menarik, dan estetis akan dapat meningkatkan sikap positif pelanggan terhadap suatu jasa. Selain itu, sikap karyawan terhadap pekerjaan dan motivasi kerjanya juga dapat meningkat. Aspek-aspek yang perlu ditata meliputi berbagai aspek. Misalnya, tinggi langit-langit bangunan, lokasi jendela dan pintu, bentuk pintu yang beraneka ragam, dan lokasi interior.

e. Masyarakat dan Lingkungan sekitar

Masyarakat (terutama pemerhati masalah sosial, dan lingkungan hidup) dan lingkungan di sekitar fasilitas jasa memainkan peranan penting dan berpengaruh besar terhadap perusahaan. Apabila perusahaan tidak mempertimbangkan faktor ini, maka kelangsungan hidup perusahaan dapat terancam.

f. Biaya kontruksi dan oprasi

Kedua jenis biaya ini dipengaruhi desain fasilitas. Biaya kontruksi dipengaruhi oleh jumlah dan jenis bahan bangunan yang digunakan. Biaya operasi dipengaruhi oleh kebutuhan energy ruangan, yang berkaitan dengan perusahaan suhu.

Penelitian yang dilakukan (Manoppo, 2013) yang berjudul " kualitas pelayanan dan servicescape pengaruhnya terhadap kapuasan konsumen terhadap hotel gran puri Manado". Sampel dalam penelitian berjumlah 70 responden. Hasil penelitian yang dilakukan menghasilkan 1) kualitas pelayanan secara simultan memiliki pengaruh secara positif terhadap kepuasan pengunjung hotel gran puri, 2) servicescrape secara simultan memiliki pengaruh secra positif terhadap kepuasan pengunjung hotel gran puri. Persamaan penelitian ini dengan penelitian sebelumnya adalah menggunakan sampel konsumen hotel, persamaan lainya kualitas pelayanan mempengaruhi penelitian sebelumnya, penlitian sebelumnya mengambil sampel konsumen hotel gran puri di Manado sedangkan penelitian ini mengambil sampel konsumen Hotel Syariah Solo, perbedaan lainnya penelitian ini tidak mengambil variabel servicescrape sebagai pengaruh terhadap kepuasan.

(Ketchand, 1998) Kualitas meliputi penilaian konsumen terhadap inti pelayanan tersebut, memberi layanan atau keseluruhan organisasi pelayanan. Kualitas adalah pertimbangan umum yang berhubungan dengan produk secara umum dan diakui bahwa kualitas pelayanan menentukan kepuasan pelanggan. Berdasarkan pada uraian teori yang telah di kemukakan serta permasalahan yang ada, maka perlu dibuat suatu kerangka konseptual penelitian. Tujuan adalah untuk memberikan kemudahan dalam mengkaji kondisi yang teliti. Adapun kerangka konseptual dalam penelitian ini dapar di lihat dalam gambar di bawah ini:

1. Pengaruh Kualitas Pelayanan terhadap Kepuasan Konsumen 
Kualitas pelayanan merupakan tingkat kondisi baik buruknya sajian yang diberikan penyedia jasa dalam rangka memuaskan konsumen, dalam perusahaan jasa tertentu bukanlah sesuatu yang mudah didefinisikan, karena hal tersebut sangat berhubungan erat dengan pandangan konsumen. Kotler (2001) menyatakan bahwa pelayanan adalah setiap kegiatan atau manfaat yang diberikan oleh suatu pihak kepada pihak lain yang pada dasarnya tidak berwujud dan tidak pula berakibat kepemilikan sesuatu. Bahwa ketika pelayanan yang diberikan mampu memenuhi atau melampaui pengharapan atau ekspektasi konsumen maka konsumen tersebut akan merasa puas. Berdasarkan pengertian di atas dapat disimpulkan bahwa kualitas pelayanan adalah ciri, karakteristik atau sifat suatu produk atau pelayanan yang berpengaruh pada kemampuan untuk memuaskan kebutuhan konsumen.

Berdasarkan uraian di atas maka dapat dirumuskan Hipotesis sebagai berikut:

$\mathrm{H}_{1}$ : Kualitas pelayanan berpengaruh secara signifikan terhadap kepuasan konsumen RS Islam di Surakarta.

2. Pengaruh Harga terhadap Kepuasan Konsumen

Harga dilihat dari sudut pandang konsumen, seringkali digunakan sebagai indikator nilai bilaimana harga tersebut dihubungkan dengan manfaat yang dirasakan atas suatu barang atau jasa. Nilai dapat didefinisikan sebagai rasio antara manfaat yang dirasakan terhadap Harga. Degan demikian dapat disimpulkan bahwa pada tingkat harga tertentu, jika manfaat yang dirasakan meningkat, maka nilainya akan meningkat pula. Apabila nilai yang dirasakan pelanggan semakin tinggi, maka akan menciptakan kepuasan pelanggan yang maksimal (Tjiptono, 2004).
Berdasarkan uraian diatas maka dapat dirumuskan hipotesis sebagai berikut:

$\mathrm{H}_{2}$ : presepsi harga berpengaruh secara signifikan terhadap kepuasan RS Islam di Surakarta.

3. Pengaruh Fasilitas terhadap Kepuasan Konsumen

Menurut Tjiptono (2004) bahwa fasilitas merupakan sesuatu yang sangat penting dalam usaha jasa, oleh karena itu fasilitas yang ada yaitu kondisi fasilitas, kelengkapan desain interior dan eksterior serta kebersihan fasilitas harus dipertimbangkan terutama yang berkaitan erat dengan apa yang dirasakan pelanggan secara langsung. Persepsi yang diperoeh dari interksi pelanggan dengan fasilitas jasa berpengaruh terhadap kualitas jasa tersebut dimata pelanggan. Dari pendapatan diatas dapat ditarik kesimpulan bahwa pengertian fasilitas dapat diartikan sebagai sarana atau segala sesuatu yang sengaja disediakan sebelum suatu jasa ditawarkan untuk dipakai dan untuk dinikmati oleh pelanggan agar memperoleh kepuasan.

Berdasarkan uraian diatas mka dapat dirumuskan hipotesis sebagai berikut:

$\mathrm{H}_{3}$ : fasilitas berpengaruh secara signifikan terhadap kepuasan konsumen RS Islam di Surakarta.

\section{Penutup}

Dari hasil penelitian dapat disimpulkan hal-hal sebagai berikut bahwa pelayanan adalah setiap kegiatan atau manfaat yang diberikan oleh suatu pihak kepada pihak lain yang pada dasarnya tidak berwujud dan tidak pula berakibat kepemilikan sesuatu. Bahwa ketika pelayanan yang diberikan mampu memenuhi atau melampaui pengharapan atau ekspektasi konsumen maka konsumen tersebut akan merasa puas. Berdasarkan pengertian di atas dapat disimpulkan bahwa kualitas pelayanan adalah ciri, karakteristik atau sifat suatu produk atau 
pelayanan yang berpengaruh pada kemampuan untuk memuaskan kebutuhan konsumen.

Berdasarkan uraian di atas maka dapat dirumuskan bahwa kualitas pelayanan berpengaruh secara signifikan terhadap kepuasan konsumen RS Islam di Surakarta. Serta presepsi harga berpengaruh secara signifikan terhadap kepuasan RS Islam di Surakarta. Dan fasilitas berpengaruh secara signifikan terhadap kepuasan konsumen RS Islam di Surakarta.

\section{Daftar Pustaka}

Abdul Manaf Bohari, C. W. (2013). The competitiveness of halal food industry in Malaysia: A SWOT -ICT Analysis. GEOGRAFIA OnlineTM Malaysia Journal of Society and Space 9 Issue 1, 1-9.

Akan, P. (1995). Dimensions of service quality: a study in Istanbul. Managing Service Quality.

Anderson, E. ., Fornell, C., \& Lehmann, D. . (1994). Customer Satisfaction, Market Share and Profitability. Journal of Marketing.

Arifin, S. (2011). Pengaruh Kepercayaan, Fasilitas dan Kualitas Pelayanan Terhadap Kepuasan Konsumen Pada Hotel Jepara Indah. Jurnal Dinamika Ekonomi Dan Bisnis, Vol.8 No.

Atkinson, A. (1988). Answering the eternal question: what does the customer want? The Cornell Hotel and Restaurant Administration Quarterly.

Barsky, J. ., \& Labagh, R. (1992a). A strategy for customer satisfaction. The Cornell Hotel and Restaurant Administration Quarterly.

Barsky, J. ., \& Labagh, R. (1992b). A strategy for customer satisfaction. The Cornell Hotel and Restaurant Administration Quarterly.

Berry, L. L., \& Yadav, M. . (1996). Capture and Communicate Value in the Pricing of Services, Sloan Management Review, pp. 41-51.

Cardozo, R. (1965). An Experimental Study of Consumer Effort, Expectations and Satisfaction. Journal of Marketing Research.
Chandra, G. (2002). Strategi dan Program Pemasaran (Edisi satu). Yogyakarta: andi.

Chi, C. G.-Q., \& Qu, H. (2008). Examining the structural relationships of destination image, tourist satisfaction and destination loyalty: An integrated approach. Tourism Management.

Choi, T. Y., \& Chu, R. (2001). Determinants of hotel guests' satisfaction and repeat patronage in the Hong Kong hotel industry. International Journal of Hospitality Management, 20(277-290).

Churchill, G. ., \& Surprenant, C. (1982). An Investigation into the Determinants of Customer Satisfaction. Journal of Marketing Research,.

Dimitriades, Z. . (2006). Customer satisfaction, loyalty and commitment in service organizations - Some evidence from Greece. Management Research News.

Doi, A. R. (1984). Shariah The Islamic Law. London: Ta-Ha Publisher.

Emzir. (2009). Metodologi Penelitian Pendidikan Kuantitatif dan kualitatif. jakarta: PT Grafindo Raja Persada.

Fandy, T. (2006). Manajemen Jasa (Edisi Pert). Yogyakarta: andi.

Fandy, T. (2008). Strategi Pemasaran Edisi ke Tiga. Yogyakarta: Andi Offset.

Faullant, R., Matzler, K., \& Füller, J. (2008). The impact of satisfaction and image on loyalty: the case of Alpine ski resorts. Managing Service Quality.

Ferdinand, A. (2000). Manajemen Pemasaran: Sebuah Pendekatan Stratejik.

Finn, M., Elliot-White, M. ., \& Walton, M. (2000). Tourism and Leisure ResearchMethods: Data Collections, Analysis and Interprtation. Harlow: Pearson.

Fornell, C. (1992). A national customer satisfaction barometer: The Swedish experience. Journal of Marketing, 56, 6-21.

Fuady, M. (2005). Hukum Pailit - Dalam Teori Dan Praktek. Bandung: PT CITRA ADITYA BAKTI.

Ganesh, Jaishankar, Arnold, M. J., \& Reynolds, K. E. (2000). Understanding the Customer Base of Service Providers: An Examination 
of the Differences between Switchers and Stayers. Journal of Marketing, 65-87.

Gendro, W. (2011). Merancang Penelitian Bisnis dengan Alat Analisis SPSS 17.0 \& Smart PLS 2.0.

Ghozali, I. (2011). Aplikasi Analisis Multivariate dengan Program IBM SPSS 19 (Edisi 5). Semarang: Badan Penerbit Universitas Diponegoro.

Giese, J. ., \& J.A, C. (2000). Defining Consumer Satisfaction.

Gitosudarmo, I. (2008). Manajemen Pemasaran (edisi pert). Yogyakarta: BPFE.

Gujarati, D. (2006). Dasar-Dasar Ekonometrika (1st ed.). Jakarta: Erlangga.

Gundersen, M. ., Heide, M., \& Olson, U. . (1996). Hotel guests' satisfaction among business travellers. The Cornell Hotel and Restaurant Administration Quarterly, Pp. 72- 81.

Guntur, E. (2010). Transformasi Manajemen Pemasaran. jakarta: Sagung Seto.

Haryanto, E. (2013). Kualitas Pelayanan, Fasilitas dan Harga Tengaruhnya Terhadap Pengguna Kepuasan Jasa Layanan pada Kantor Samsat Manado. Jurnal EMBA Vol.1 No.3 September 2013, 750-760.

Henderson, J. (2010). Sharia-Compliant Hotels.Tourism and Hospitality Research 2010, Volume 10, 246-254.

Irawan, H. (2004). 10 Prinsip Kepuasan Pelanggan. Paradigma baru merebut hati pelanggan untuk memenangkan persaingan. jakarta: PT Elex Media Komputindo.

Kandampully, J., \& Suhartanto, D. (2000). Customer loyalty in the hotel industry: the role of customer satisfaction and image. International Journal of Contemporary Hospitality Management.

Ketchand, D. dan. (1998). Manajemen Pemasaran. Suatu Pendekatan Strategi Oriental (edisi kedu). jakarta: Erlangga.

Knutson, B. (1988). Frequent travellers: making them happy and bringing them back. The Cornell Hotel and Restaurant Administration Quarterly.

Kotler, P. (2001). Manajemen Pemasaran: Analisis, Perencanaan, Implementasi, dan Kontrol. jakarta: PT Prehallindo.
Kotler, P. (2005). Manajemen Pemasaran Analisis, Perencanaan dan Pengendalian. jakarta: Erlangga.

Kotler, P., \& Armstrong, G. (2006). Prinsipprinsip Pemasaran (Edisi Kedu). jakarta: Erlangga.

Kotler, P., \& Keller, K. L. (2006). Marketing Management. Pearson Education, Inc.

Legoherel, P. (1998). Quality of tourist services: The influences of each participating component on the customer's overall satisfaction regarding tourist services during a holiday. Proceedings of the Third International Conference on Tourism and Hotel Industry in Indo-China and Southeast Asia: Development, Marketing, and Sustainability, 47-54.

Lovelock, C., \& Wright, L. K. (2007). Manajemen Pemasaran Jasa. Pt Indeks.

Luo, X., \& Homburg, C. (2007). Neglected Outcomes of Customer Satisfaction. Journal of Marketing.

Lupiyoadi, Rambat, H. (2006). Manajemen Pemasaran Jasa. jakarta: Salemba Empat.

Lupiyoadi, R. (2001). Manajemen Pemasaran Jasa. jakarta: Salemba Empat.

Lupiyoadi, R. (2013). Manajemen Pemasaran Jasa (2013th ed.). jakarta: Salemba Empat.

Malik., Mudasar, Ghafoor, \& Iqbal, K. (2012). Impact Of Brand Image, Service Quality And Price On Customer Satisfaction In Pakistan Telecommunication Sector. International Journal of Business and Social Science. Vol. 3 No. 23; December 2012.

Manoppo, F. (2013). Kualitas Pelayanan dan Servicescape Pengaruhnya Terhadap Kepuasan Konsumen Pada Hotel Gran Puri Manado.

Mohd Rizal Razalli, S. A. (2012). Developing a model for Islamic hotels: Evaluating opportunities and challenges, 91-95.

Nor'ain Othman, R. M. (2015). Maqasid Al Shariah In The Governance And Management Strategy Of Islamic Tourism Businesses.

Oh, H., \& Parks, S. (1997). Customer satisfaction and service quality: a critical review of the literature and research implications for the 
hospitality industry. Hospitality Research Journal.

Oliver, R. . (1980). A Cognitive Model of the Antecedents and Consequences of Satisfaction Decisions. Journal of Marketing Research, Vol. 17, 460-469.

Olorunniwo, F., Hsu, M. ., \& Udo, G. J. (2006). Service quality, customer satisfaction and behavioural intentions in the service factory. Journal of Services Marketing.

Ratminto, \& Winarsih, A. (2005). Manajemen Pelayanan. Yogyakarta: Pustaka Pelajar.

Ratnasari, R. T., \& Mastuti, A. (2011). Manajemen Pemasaran Jasa.

Rosenberg, P. a. (2009). Spiritual Lodging- The Shariah Compliant Hotel Concept.

Salleh, N. Z. M., Hamid, A. B. A., Hashim, N. H., \& Omain, S. Z. (2014). The Practice of Shariah-Compliant Hotel in Malaysia, (ISSN: 2010-023X).

Samori, Z., \& Abd Rahman, F. (2013). Towards the Formation of Shariah Compliance Hotel in Malaysia:An Exploratory Study on its Opportunities and Challenges,.

Shamim, Y. (2009). The real sense of Shariah hospitality concept. In World Halal Forum, Kuala Lumpur, Malaysia.

Skogland, I. \& Siguaw, J. A. (2004). Are your satisfied customers loyal? Cornell Hotel and Restaurant Administration Quarterly.

Söderlund, M. (1998). Customer satisfaction and its consequences on customer behaviour revisited: The impact of different levels of satisfaction on word-of-mouth, feedback to the supplier and loyalty. Journal of Service Industry Management.

Sugiyono. (2004). Metode Penelitian Bisnis. Bandung: CV Alfabeta.

Sugiyono. (2009). Metode Penelitian Bisnis (Pendekatan Kuantitatif, Kualitatif, dan $R \& D)$. Bandung: CV Alfabeta.

Suhaiza Zailani, A. O. (2011). An Exploratory Study on the Factors Influencing the NonCompliance to Halal Among Hoteliers in Malaysia. International Business Management, 1-12.

Sulistiyana, Djamhur, Hamid, \& Azizah, D. F.
(2015). Pengaruh Fasilitas Wisata Dan Harga Terhadap Kepuasan Konsumen (Studi Pada Museum Satwa). Jurnal Administrasi Bisnis, Vol. 25 No.

Suliyanto. (2005). Analisis Data Dalam Aplikasi Pemasaran”. Bogor, Indonesia: Ghalia Indonesia.

Supranto, J. (2001). Pengukuran Tingkat Kepuasan Pelanggan: Untuk Menaikkan Pangsa Pasar. jakarta: Rineka Cipta.

Tandjung, W. (2004). Marketing Management Pendekatan pada Nilai-nilai Pelanggan. Malang: banyumedia.

Tho'in, M. (2016). Kompetensi Sumber Daya Manusia Bank Syariah Berdasarkan Prinsip-Prinsip Syariah Islam (Studi Kasus Pada BNI Syariah Surakarta). Jurnal Ilmiah Ekonomi Islam, 2(03).

Tho'in, Muhammad. 2011. Pengaruh Faktorfaktor Kualitas Jasa terhadap Kepuasan Nasabah di Baitul Maal wat Tamwil (BMT) Tekun Karanggede Boyolali. Muqtasid Jurnal Ekonomi dan Perbankan Syariah STAIN Salatiga. Vol. 2, Juli 73-89.

Thorik, G., \& Utus, H. (2006). Marketing Muhammad. jakarta: Gema Insani Press.

Tjiptono. (2004). Pemasaran Jasa. Malang: Bayu Media.

Wan Shahida, S. K. (2011). The Implementation of Shariah Compliance Concept Hotel: De Palma Hotel Ampang, Malaysia. 2nd International Conference on Humanities, Historical and Social Sciences (IPEDR), 138-142.

Yeung, M., Ging, L., \& Ennew, C. (2000). Customer satisfaction and profitability: a reappraisal of the nature of the relationship. Journal of Targeting, Measurement and Analysis for Marketing.

Zafir, N., Bakar, A., \& Hashim. (2014). The Practice of Shariah-complaint hotel in Malaysia. Internasional Journal of Trade, Economics and Finance.

Zeithaml, V., \& Bitner, M. J. (2003). Services Marketing: integrating customer focus across the firm, 3rd edition, McGrow-Hill. 